\title{
A Comparative Study of Inferential Comprehension Strategies Between A Language-Learing Disabled and Non Language-Learning Disabled Child
}

\author{
Yael Tombak, BA (Speech and Hearing Therapy) (Witwatersrand) \\ Glenda Shapiro, BA (Log) (Witwatersrand) \\ Department of Speech Pathology and Audiology, \\ University of the Witwatersrand, Johannesburg
}

\section{ABSTRACT}

The aim of this study was to analyse and compare the inferential comprehension strategies used by a language-learning disabled and non language-learning disabled subject, as well as to investigate their performance on areas related to inferential comprehension. For these purposes, tests were either constructed or modified in order to allow for qualitative analysis of the subjects' responses and the strategies used.

The non language-learning disabled subject was found to utilize efficient inferential strategies, suggestive of cognitive-linguistic integrity, whereas the language-learning disabled subject was found to use inefficient inferential strategies and to be deficient on several areas related to inferential comprehension. These findings are interpreted as being reflective of a breakdown in the interactional dynamics between cognition and language.

\section{OPSOMMING}

Die doel van hierdie studie was om die afleidende-begripsstrategieë wat deur ' $n$ taalleergestremde en 'n nie-taalleergestremde proefpersoon gebruik word, te ontleed en te vergelyk. Hulle prestasie in aspekte wat aan afleidende begrip verwant is, is ook ondersoek. Vir hierdie doel is toetse opgestel of aangepas om kwalitatiewe ontleding van die proefpersone se response en die strategieë wat hulle gebruik, uit te voer.

Die nie-taalleergestremde kind het doeltreffende afleidende strategiee gebruik wat kognitiewe linguistiese integriteit aandui. Die taalleergestremde kind het ontoereikende strategieë gebruik en was ook ondoeltreffend in aspekte wat aan afleidende begrip verwant is. Die bevindings word interpreteer as bewys van 'n disintegrasie van die interafhanklike dinamiek tussen kognitiewe en linguistiese funksie.

Inferential comprehension refers to the listener's ability to use his real world knowledge, in combination with linguistic information to go beyond the explicitly stated information. Thus, a person's ability to engage in inferential comprehension depends on active participation, as well as utilization of a wide variety of stored information, pragmatics and author-reader conventions (Thorndyke, 1976). Inferential ability is an important component of comprehension and communication. Furthermore, it is an important prerequisite for dealing with information in many academic tasks (Klein-Konigsberg, 1984). The principles of inferential ability are important in reading comprehension (Kail et al. 1977). Furthermore, language demands placed on students in the academic setting require them "to understand and follow the teacher's directions and to focus and derive main ideas from the teacher's lecture, to organize and store these facts for retrieval" $1 \mathrm{O}^{\prime}$ Connor and Eldredge, cited by Nelson, 1986).

Both cognitive and linguistic hypotheses have been proposed to explain inferential disability |Crais and Chapman, 1987; Ellis Weismer, 1985) but only recently has inferential comprehension become an area of interest in the field of language pathology and learning disabilities (Freston and Drew, cited by Crais and Chapman, 1987; Ellis Weismer, 1985; Klein-Konigsberg, 1984). Until recently, most studies of language-disabled children have focused primarily on syntax and morphology (Wiig and Semel, 1981). The recent shift toward the study of this area - previously the domain of psychological research (Bransford and Franks, 1971; Johnson, Bransford and Solomon, 1973; Paris and Carter, 1973; Paris and Lindauer, 1976 - holds significant theoretical and practical implications relevant to the field of language problems. These implications could have an impact on our current conceptualization of cognitive and linguistic processes that operate in various language disorders, and on the ensuing course of intervention.

Previous research on inferential ability has revealed some interesting trends. For example, it was noted that younger children lacked a deliberate strategic approach when engaging in inferential comprehension tasks (Paris and Lindauer, 1976). Younger children experienced difficulty integrating premises and manipulating linguistic information in memory, and their schemata were fragmented (Danner \& Mathews, 1980). Older children were found to employ more deliberate metamemorial strategies to integrate premises (Paris \& Lindauer, 1976). Their verbal representational skills were superior and their schemata richer and more comprehensive (Danner \& Mathews, 1980). In the light of this developmental perspective it was hypothesized that perhaps language-learning disabled children would use earlier developing strategies which are less goal-orientated and task-appropriate. 
There has been little research into deficient inferential abilities. As with the research on the normal inferential process, these studies were flawed by the lack of an adequate conceptual model or systematic delineation of the abilities examined. Despite the scarcity of research on inferential disability in the language-learning disabled population, some trends have emerged from the literature. For example, Snyder (cited by Ellis Weismer, 1985) noted that languagelearning disabled children made fewer inferences as do younger children, and also that their performance is characterized by difficulties with simultaneous analysis and synthesis of information. Some writers (Carroll, 1986), have suggested that the language-learning disabled children have poorly integrated schemata, whilst Crais and Chapman (1987) attributed inferential disability to poor verbal comprehension.

Recent literature on the nature of learning disabilities reflects an orientation which considers strategic inefficiency to be central to academic under-achievement (Reed \& Hresko; Torgeson; cited by Wiig and Secord, 1985). Therefore, the primary aim of this study (Tombak, 1987) was to analyse and compare the inferential comprehension strategies used by a language-learning disabled and non languagelearning disabled child. A strategy-based approach was used as it was considered to be a valid method for qualitative investigation of linguistic cognitive processes. With this in mind, the writer (Tombak, 1987) conceptualised a model of inferential comprehension in which the inferential comprehension process may be viewed as an interaction between the text and what the listener brings with him to the comprehension process, resulting in the product or inference (see figure 1).
The contextual basis of inferential ability was considered in terms of the 'microstructure' (Carroll, 1986), and the linguistic factors which may affect comprehension. Listener variables were considered in terms of macrostructure and schematic knowledge. These refer to the listener's know. ledge of the standard arrangement of information and gene. ralized experiential knowledge respectively (Moates and Schumacher, 1980). Problem-solving strategies were also taken into account. Lastly, the final inference product was analysed in terms of inferential subject matter and the role of an interceding inference.

This model attempted to delineate the main factors involved in the inferential comprehension process. It also aimed to provide a method of systematic task analysis, in order to establish and interpretive basis for the subjects' inferential performance and the strategies used.

\section{AIMS}

The primary aim of this study was to analyse and compare the inferential comprehension strategies used by a languagelearning disabled and non language-learning disabled child. The specific aims of the study were to describe the different inferential strategies used by these two children in a systematic, qualitative manner and to investigate the influence of selected task factors on the strategies used.

\section{SUBJECT DESCRIPTION}

S1 was a 13.0 year old learning-disabled male. He was a standard 5 pupil at a remedial school which he had been attending for the past 2 years. On the Wechsler Intelligence

Figure 1: Model of inferential comprehension

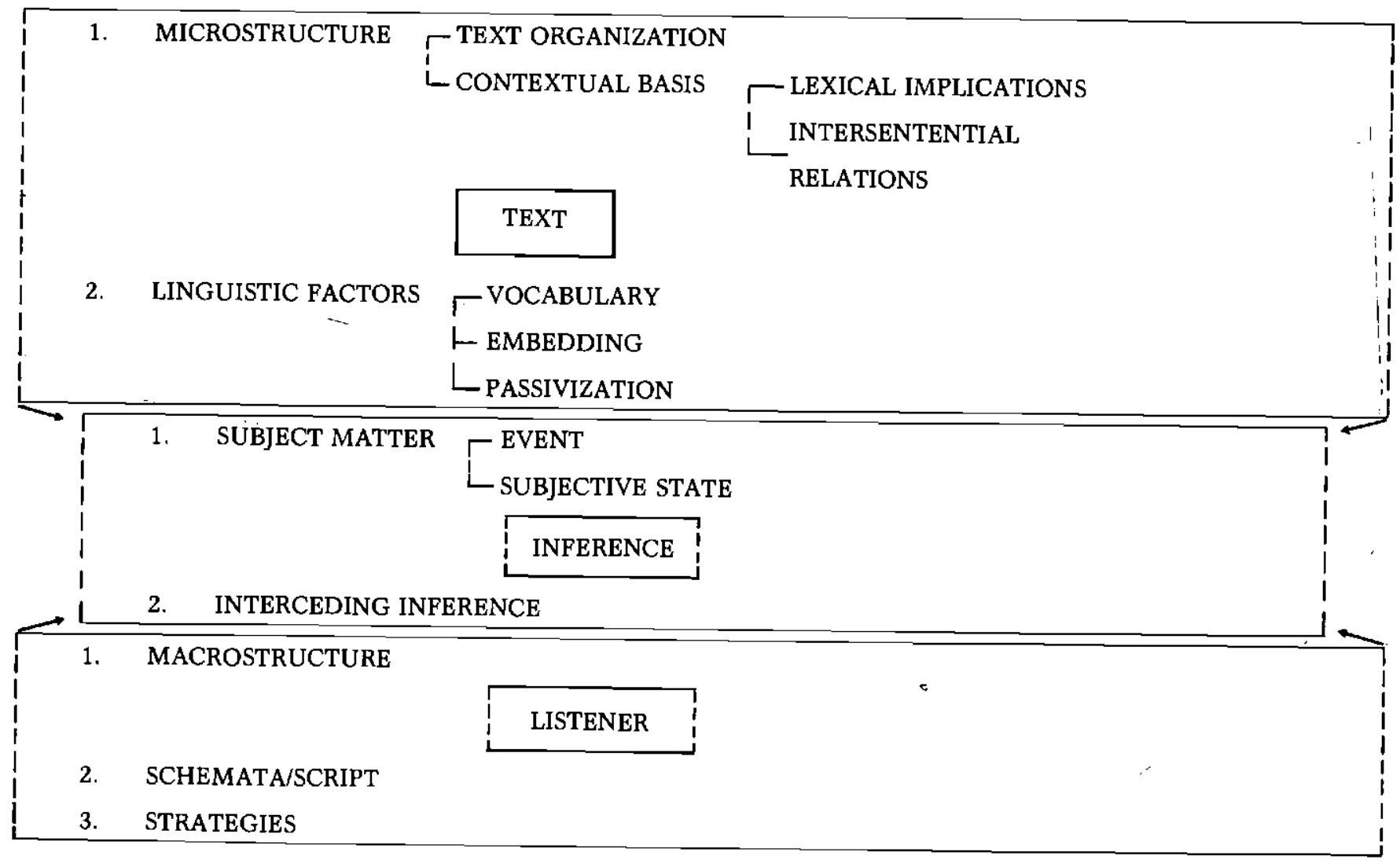


Scale for Children - Revised, he obtained a Full Sclae Intelligence Quotient of 101, indicating intellectual functioning within the normal range. There was no significant discre. pancy between his Verbal and Performance Intelligence Quotients. S1 experienced difficulty in the areas of reading and spelling, scoring 2-4 years below his chronological age level on formal reading and spelling tests. Narrative language sampling and formal testing of auditory memory for paragraphs and story material (see table 1, Criterion Tests), revealed age-appropriate performance. Language comprehension was not considered a subject selection criterion because this component was evaluated as a correlation factor to inferential ability.

S2 was a 12.9 year old non learning-disabled male in standard 5 at a regular school. There was no history of academic difficulty and school progress was good. Narrative language sampling and formal testing of auditory memory for paragraphs and story material (see table 1, Criterion Tests), revealed age-appropriate performance.

\section{DESCRIPTION OF TEST BATTERY (see table 1)}

Expressive Language Tasks (Westby, 1984)

Expressive language was evaluated using three narrative language tasks: a sequence story narrative, poster picture narrative and personal narrative. Responses to the stimuli were evaluated in terms of 'spontaneous inferencing', or spontaneously generated inferential elaboration.

\section{b) CORRELATION TESTS}

Adequate grammatic comprehension, receptive vocabulary and schematic knowledge are considered to be critical for linguistic comprehension. These areas were tested to examine the relationship between these factors and inferential ability.

\section{GRAMMATIC COMPREHENSION TESTS}

Test of Adolescent Language (T.O.A.L.; Hammill et al. 1980) Subtest 2 - Listening/Grammar

\section{Embedding test}

This test was adapted from a test constructed by Penn (1972) and was designed to assess comprehension of relative, complement and multiple-embedded sentences.

Table 1: The test battery

\begin{tabular}{|c|c|c|}
\hline CRITERION TESTS & CORRELATION TESTS & MAIN TESTS \\
\hline $\begin{array}{l}\text { 1. C.E.L.F.:- Subtest } 6 \text { (Semel \& } \\
\text { Wiig, 1980) }\end{array}$ & $\begin{array}{l}\text { 1. T.O.A.L.:- Subtest } 2 \text { (Hammill } \\
\text { et al. 1980) }\end{array}$ & 1. Spontaneous inferencing \\
\hline $\begin{array}{l}\text { 2. Story recall "The stork in the } \\
\text { wheat" (Berry, 1969) }\end{array}$ & $\begin{array}{l}\text { 2. Embedding Test (Adapted from } \\
\text { Penn, 1972) }\end{array}$ & $\begin{array}{l}\text { 2. T.O.L.C:- Subtest } 2 \text { (Wiig \& } \\
\text { Secord, } 1985 \text { ) }\end{array}$ \\
\hline $\begin{array}{l}\text { 3. Narrative tasks:- Sequence } \\
\text { story, Poster Picture and Perso- } \\
\text { - nal Narratives (Westby, 1984) }\end{array}$ & $\begin{array}{l}\text { 3. Wiig-Semel Test Passive Con- } \\
\text { cept (Wiig \& Semel, 1976) }\end{array}$ & $\begin{array}{l}\text { 3. Inferential Comprehension } \\
\text { Test } 1\end{array}$ \\
\hline : & $\begin{array}{l}\text { 4. P.P.V.T.:- Form A } \\
\text { (Dunn, 1965) } \\
\text { 5. Schema Test (Adapted from } \\
\text { Bower, Black \& Turner; cited by } \\
\text { Reed, 1982) }\end{array}$ & $\begin{array}{l}\text { 4. Inferential Comprehension Test } \\
\text { 2:- Microstructure, Embed- } \\
\text { ding, Passivization, Vocabular- } \\
\text { ly, Interceding, Inference }\end{array}$ \\
\hline
\end{tabular}

The test battery administered was considered under the following three categories:

a) Criterion tests: These were tests utilized to assess the subject's fulfilment of preselection criteria.

b) Correlation tests: These tasks were used to evaluate the subjects' performance in areas related to inferential comprehension.

c) Main test: These constituted the primary tests of inferential comprehension.

\section{a) CRITERION TESTS}

\section{Tests of Auditory Memory}

Clinical Evaluation of Language Functions IC.E.L.F., Semel and Wiig, 1980) Subtest 6-Processing Spoken Paragraphs.

Story recall (Berry, 1969) A test story, "The stork in the wheat", was used to measure retention and recall of salient sequential information in a story.
Wiig-Semel Test of Linguistic Concepts - Passive Concept (Wiig \& Semel, 1976)

\section{RECEPTIVE VOCABULARY}

Peabody Picture Vocabulary Test - Form A (P.P.V.T.; Dunn, $1965 \mid$.

\section{SCHEMATIC KNOWLEDGE}

\section{Schema Test}

This test, adapted from Bower, Black and Turner (cited by Reed, 1982), was designed to assess the comprehensiveness of the subjects' schemata for five common situations involv. ing event and action sequences.

\section{c) MAIN TESTS}

\section{'Evaluation of spontaneous inferencing}

The sequence story and poster narratives were analysed in 
terms of the spontaneous inferences generated.

Test of Language Competence (T.O.L.C.: Wiig and Secord, 1985) Subtest 2 - Making Inferences (see Appendix 1)

This subtest evaluated the ability to make causal inferences based on existing event chains in which one or more causal links were missing. Where appropriate, the subjects were probed for linguistic explanation, justification and elabora. tion of their responses.

\section{Inferential Comprehension Test 1 (see Appendix 2)}

This was the first of two tasks devised by the experimenter, specifically for this study, in order to evaluate inferential strategies. Items consisted of sentence pairs followed by a question, and were organized according to the conceptual model outlined earlier (see figure 1). The inferential abilities required for these tasks were primarily based on real world knowlege. The tasks were linguistically simple to minimize the influence of linguistic factors.

\section{Inferential Comprehension Test 2 (see Appendix 3)}

This test used a paragraph format and was more reliant on linguistic factors for comprehension. Each of the factors considered was represented by a pair of thematically similiar paragraphs, one of which was systematically varied with regard to that factor. Each paragraph was followed by questions and probing.

\section{METHODS OF ANALYSIS}

\section{CRITERION AND CORRELATION TESTS}

These were scored according to test manual instructions, or specially devised scoring systems for each test, which were constructed for the purpose of the study.

\section{MAIN TESTS}

\section{Evaluation of 'Spontaneous Inferencing}

The number of spontaneous inferences generated by the subjects was calculated and the nature of the inferences qualitatively described.

Test' of Language Competence - Subtest 2 (Wiig and Secord; 1985)

Four analyses were carried out on the response data obtained:-

Quantitative analysis - Scoring based on point calculation was utilised.

Quantitative analysis of strategies - The T.O.L.C. responses were analised qualitatively by the examiner. The responses were organized by the examiner into 12 major categories of deficient strategies (see Results Section).
Divergent shift analysis - This analysis considered the subjects' ability to make divergent conceptual shifts.

Congruency analysis - This analysis considered the sub. jects' attention to semantic congruency between response alternatives.

\section{Test of Inferential Comprehension 1}

The responses were qualitatively analysed in terms of strategies.

\section{Test of Inferential Comprehension 2}

The paragraph pairs were analysed in terms of strategy patterns, divergence, and the effect of factor variation on performance.

\section{RESULTS AND DISCUSSION}

The subjects' performance on the criterion, correlation and main tests were analyzed quantitatively and qualitatively, and compared. Their responses on the main tests were considered to reflect the inferential strategies utilized.

\section{a) CRITERION TESTS}

Both subjects scored above the revised pass-fail criterion of 14 on the C.E.L.F. - Subtest 6 (Semel \& Wiig, 1980) indicating the presence of adequate auditory memory for paragraph material. On the story memory task (Berry, 1969), both subjects scored above $70 \%$, calculated using a scoring system devised by the examiner (Tombak, 1987). The scores were interpreted as reflective of adequate auditory memory for complex story material. Both subjects fulfilled the criterion of adequate verbal expression on the narrative task battery. However, although both subjects were able to verbally express their ideas in a clear manner, their expressive abilities differed along the dimensions of spontaneous inferencing and coherence in favour of S2.

\section{b) Correlation Tests (see Table 2)}

S1's performance was below average on the following tasks:

- T.O.A.L. - Subtest 2 (Hammill et al. 1980)

- Embedding Test

- Test of Linguistic Concepts - Passive Concept (Wiig \& Semel, 1976)

- Description of schematic events, which was fragmented.

S1 performed adequately on the P.P.V.T. - Form A (Dunn, 1965)

S2's performance was average to above-average on all the above tasks. Of significance was his much superior performance on the P.P.V.T. - Form A (Dunn, 1965), 
Table 2: Correlation tests

\begin{tabular}{|c|c|c|}
\hline & S1 & S2 \\
\hline T.O.A.L. & $\begin{array}{l}\text { Below average } \\
\text { Scaled score }=5\end{array}$ & $\begin{array}{c}\text { Average } \\
\text { Scaled score }=10\end{array}$ \\
\hline Embedding Test & $\begin{array}{c}\text { Poor } \\
\text { Percentage }=43 \%\end{array}$ & $\begin{array}{c}\text { Good } \\
\text { Percentage }=87 \%\end{array}$ \\
\hline Wiig - Semel Test & $\begin{array}{c}\text { Std } 1 \text { level } \\
\text { Percentage }=70 \%\end{array}$ & $\begin{array}{c}\text { Std } 6 \text { level } \\
\text { Percentage }=100 \%\end{array}$ \\
\hline P.P.V.T. & $\begin{array}{c}\text { Average } \\
\text { Mental age }=12.7 \text { yrs } \\
\text { Percentile }=45\end{array}$ & $\begin{array}{c}\text { Above average } \\
\text { Mental age }=18+\text { yrs } \\
\text { Percentile }=94\end{array}$ \\
\hline Schema Test & $\begin{array}{c}\text { Poor } \\
\text { Raw score }=27\end{array}$ & $\begin{array}{c}\text { Good } \\
\text { Raw score }=41\end{array}$ \\
\hline
\end{tabular}

\section{c) MAIN TESTS}

\section{'Evaluation of Spontaneous Inferencing}

There was a marked difference between the subjects' spontaneous inferencing abilities, both quantitatively and qualitatively.

Spontaneous inferencing was measured quantitatively in units, each unit being an inferential proposition or item of information. This scoring system was developed for the purpose of the study (Tombak, 1987). Unit scoring was carried out by the examiner. S1 generated a total of 4 units (picture Narrative -2 units, Poster Narrative -2 units), in contrast to a total of 30 units produced by S2 (Picture Narrative -12 units; Poster Narrative -18 units).

S1's narratives lacked elaboration, and were concrete and highly stimulus-bound, and there was inadequate thematic content. S2's inferences were complex narrative sequences elaborating on preceding and consequent events, motivations and internal states.

Figure 2: Strategy analysịs

\begin{tabular}{|ll|}
1.1 & Concretism \\
1.2 & Conceptual syncretism \\
2. & Lexical syncretism \\
3. & Psychological explanation \\
\hline
\end{tabular}
4. Linguistically-contradictéd divergence
5. Linguistically-unsupported divergence
6. Literal comprehension difficulty

7. Illogical inference i.t.o. Real world knowledge

8. Non-optimal inference i.t.o. Real world knowledge

9. Inversed cause-effect reasoning

10. Egocentric reasoning

11. Interceding inference

12. Alternative inference
Test of language competence

Quantitative analysis:-

S1 experienced great difficulty with inferential reasoning, and selected a low proportion $(43 \%)$ of correct inferential responses, while S2 selected a high proportion $(87 \%)$ of correct responses.

Qualitative analysis:-

This analysis was devised to compare and contrast the nature of the deficient strategies used by the 2 subjects. As stated earlier, the responses were organized by the examiner into 12 categories of deficient strategies (see figure 2).

The first ten of these were grouped into four strategy clusters, designated by the letters (A) - (D). Each cluster corresponded to a number of ineffective ways of implementing a constructive strategy.
STRATEGY CLUSTER A:

Divergent thinking

\section{STRATEGY CLUSTER B:}

Convergent thinking

\section{STRATEGY CLUSTER C:}

Utilization of real world knowledge

STRATEGY CLUSTER D:

Causal reasoning 


\section{A. Strategy cluster $A$}

This cluster was related to difficulty with divergent thinking.

\subsection{Concretism}

Concretism refers to the inability to go beyond the linguistic context presented. A concrete answer lacks hypotheticodeductive reasoning.

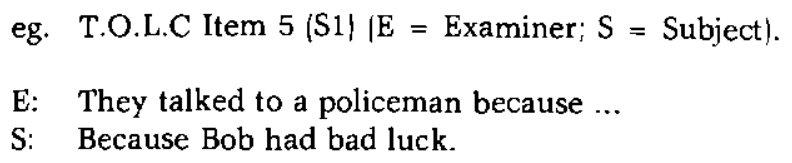

This category occurred frequently in S1's responses as opposed to S2's, where no instances were noted. S1 relied heavily on linguistic context, reflecting deficient hypothetical reasoning. In contrast, S2's responses were hypotheticodeductive.

\subsection{Conceptual syncretism}

Conceptual syncretism is a Piagetian concept which refers to a tendency found in preoperational and concrete operational thought - to juxtapose rather than synthesise logical and causal relations (Piaget, 1927). A syncretic response is characterised by an indiscriminate linkage of two verbal statements with no consideration of their conceptual relationship.

\section{eg. T.O.L.C Trial Item $[S 1]$}

E: They had to go to eat at a restaurant because...

S: They had a turkey at home and they wanted to eat at a restaurant.

This strategy occurred exclusively in S1's responses. Due to S1's inability to go beyond the linguistic context into the realm of hypotheses, he adopted the strategy of randomly juxtaposing any two salient concepts presented simultaneously, and forming a syncretic connection.

S2's reasoning, in contrast, was highly divergent and hypothetical. S1's deficit was characteristic of preoperational difficulty with constructing relationships that reflect attention to and simultaneous retention of all critical relevant information. Previous investigations have also documented difficulties in simultaneous analysis and synthesis of information in learning-disabled children (Crais and Chapman, 1987; Gerber, 1981; Klein-Konigsberg, 1984|.

\section{Lexical syncretism}

This term refers to the tendency to juxtapose any two lexical items indiscriminately, with no apparent conceptual basis for this fusion.

eg. T.O.L.C. Trial item (S1)

E: Do you have any idea why ... they weren't able to eat at home?

\section{$\mathrm{S}: \quad$ Because the house was trimming}

This tendency was a unique feature observed in S1's responses, and appeared to be a primitive, and possibly deviant manifestation of conceptual syncretism, which resulted in distortion of the relationships depicted. 51 resorted to this preoperational strategy when he experienced a compre. hension breakdown. A similar finding was also reported by Klein-Konigsberg (1984) who found that language-learning disabled children tended to attend to smaller sentence constituents when applying integrational strategies.

\section{Psychological explanation}

This refers to the preoperational tendency to provide a psychological explanation when a casual event explanation would be more appropriate (Piaget, 1927).

\section{eg. T.O.L.C. Item 1 (S1)}

E: Jack didn't leave a tip because ...

S: He didn't-feel like leaving a tip.

S1 tended to give psychological explanations of events, while S2 formulated hypothetical causal events.

Cluster $A\{1,2,3\}$ represented deficits in divergent thinking. $S 1$ 's responses were overreliant on linguistic contest, and reflected analytic deficits. S1 lacked the ability to depart from reality. The strategies used by $\mathrm{S} 1$ interfered with divergence and the ability to formulate causal event relationships. Snyder (cited by Ellis Weismer, 1985) also reported diver. gence deficits in a group of language-disordered children studied.

\section{B. Strategy cluster B}

This cluster represented problems with converging to the linguistic context.

\section{Linguistically-contradicted divergence}

This feature is associated with the tendency to ignore or misinterpret critical linguistic sequences, due to insufficient cognizance of linguistic information that suggests a contrary direction or focus of inferential convergence.

eg. T.O.L.C. Trial Item [S1]

E: They had to eat at a restaurant because ...

S: They had a turkey at home and they wanted to eat at a . restaurant.

S1 used this strategy frequently, often ignoring or misinterpreting salient linguistic information. This feature also occurred in S2's responses to a lesser extent. It appeared that S1's preoperational difficulty with simultaneous analysis and synthesis of information, resulted in unpermissible divergent responses.

eg. T.O.L.C. Item 6 (S1)

E: Eric was grateful to his Uncle Fred because ...

S: (selects alternative a:) Uncle Fred bought himself a moped ... because his uncle didn't have a bike and then he bought one.

This strategy occurred frequently in S1's responses, in those 
instances when he did attempt to diverge beyond the linguistic context but it did not occur in S2's responses. This strategy was used when the linguistic context was not fully understood, due to fragmented lexical schemata. Poor assi. milation and accommodation strategies may account for such deficient schemata.

\section{Literal comprehension difficulty}

This refers to difficulty in comprehending the basic relationships depicted, due to vocabulary deficits.

eg. T.O.L.C. Trial item (S1)

E: Do you have any idea why ... they weren't able to eat at home?

S: Because the house was trimming.

Literal comprehension deficits were rare in S1's responses and absent from $\mathrm{S} 2$ 's responses on this test.

Strategy cluster $B(4,5,6)$ represented deficits in linguistic convergence. S1 failed to perceive several lexical implications and their interactions simultaneously, reflecting a preoperational tendency to attend to only one feature or property at a time (Wiig \& Semel, 1984). S2, on the other hand was able to attend to the full scope of the linguistic information presented, resulting in "lawful divergence" (Phillips, 1971). Difficulties in simultaneous analysis and synthesis have been noted in language-learning disabled children (Crais and Chapman, 1987; Ellis Weismer, 1985; KleinKonigsberg, 1984) as well as younger normal children (Paris and Lindauer, 1976).

\section{Strategy cluster $C$}

This cluster was related to ineffective utilization of real world knowledge.

7. Illogical inference in terms of real world knowledge

This feature refers to the formulation of inferences which are implausible in terms of real world knowledge.

eg. T.O.L.C. Item 5 (S1)

E: They talked to a policeman because ...

S: ... Because they rode on a crowded bus.

Only $\$ 1$ formulated inferences that were implausible in terms of real world knowledge. It seemed that S1 had not acquired comprehensive schemata, as indicated by his performance on the Schema Test. His schemata appeared to lack refinement, and resisted absorption of new information. This deficit could also be related to inadequate accessing as well as induction of schemata (Carroll, 1986).

8. Non-optimal inference in terms of real world knowledge

This feature is characterised by the formulation of plausible, but unlikely inferences due to inefficient utilization of real world knowledge.

eg. T.O.L.C. Item 1 (S1)
E: Jack didn't leave a tip because ...

S: He didn't feel like it ... He was unkind.

S1 tended to make illogical inferences, in contrast to S2 whose inferences were always plausible, although not always probable.

Strategy cluster $C(7,8)$ was concerned with the utilization of schematic knowledge in generating logical inferences. Fragmented schemata result in implausible or non-optimal inferences. This strategic failure could be caused by poorly induced schemata or failure to access the appropriate schemata timeously.

\section{Strategy cluster $D$}

This strategy was related to causal reasoning.

\section{Inversed cause-effect reasoning}

This feature refers to reasoning which is characterised by inadequate distinction between and sequencing of cause and effect events. Inversed causal reasoning is characteristic of preoperational and concrete operational thinking and is associated with egocentrism and a tendency towards syncretic perception \{Phillips, 1971).

\section{eg. T.O.L.C. Item $5[S 1]$}

E: They talked to a policeman because ..

S: (selects d:) Bob lost his money sometime before they got to the mall ... because they couldn't pay for the bus.

The expression of the causal relationship was inversed by $\mathrm{S} 1$ and an effect was formulated instead of a caúse. S1's responses were characterised by deficient causal reasoning as his concept of 'because' was associated with a sequential meaning, rather than a true concept of causality. S2's reasoning was characterised by explicit delineation of causeeffect relationships and he was able to distinguish clearly between cause and effect.

\section{Egocentric reasoning}

Egocentric explanations are characterised by presupposition of the listener's knowledge of the speaker's internal reasoning process. Egocentric reasoning is a characteristic of preoperational thought.

\section{eg. T.O.L.C. Item 1 (S1)}

E: He didn't leave a tip because ...

S: (selects a) The restaurant closed when he arrived.

E: Why do you think that's a good answer?

S: Because he didn't leave the waiter a tip.

$\mathrm{E}$ : and $\mathrm{cl}$, 'The food and service were excellent?

$S$ : Yes, the food and service were excellent.

Egocentric reasoning was a common feature of S1's reasoning while only one instance was observed in S2's responses. Egocentric explanations are characteristic of preoperational reasoning, and are caused by a lack of concern for the listener's perspective (Piaget, 1923). 
Strategy cluster $D(9,10)$ was concerned with the role of causal reasoning in inferencing. S1's reasoning was characterised by poor comprehension of cause-effect relationships and egocentrism, reflective of a cognitive developmental lag (Phillips, 1971). S2 was able to engage in formal-operational explicit causal reasoning.

\section{Interceding inference}

When a final inference relies on an intermediate step or inference, the task is complicated since a faulty interceding inference may lead to the induction of a faulty final inference.

eg. T.O.L.C. Item 9 (S1)

Lori took the bus downtown because it was her mother's birthday. She left the fashionable stores with tears in her eyes.

E: Lori cried because ...

S: Maybe her mother didn't have any money with her so she could buy clothes and that ...

The interceding inference that 'Lori went to town to buy her mother a birthday present' was not included. S1's inferential reasoning frequently broke down as a result of faulty interceding inferences. S2 was generally able to generate correct interceding inferences.

\section{Alternative inference}

This category was related to difficulty with divergent conceptual shifting.

eg. T.O.L.C. Item 6 (S1)

E: Eric was grateful to his Uncle Fred because ...

S: Because his uncle let him use the bike for a long time.

$\mathrm{E}$ : Can you think of another reason why he was grateful?

S: Because his uncle let him ride it.

S1 consistently offered a paraphrase of previous explanations as an alternative inference, retaining the same conceptual basis for all interpretations (Wiig \& Secord, 1985). S2's responses were characterised by alternative interpretations and a more divergent orientation. S1's responses reflected deficits in divergent conceptual shifting, resulting in overreliance on linguistic context. This finding was in agreement with that of Snyder (cited by Ellis Weisman, 1985) who found that language-disordered children made fewer in. ferences than age peers. Difficulty with conceptual shifting has also been documented in the learning disabled population (Wiig \& Semel, 1976).

The difference in divergence abilities appeared to be diagnostically significant. This deficit appeared to be central to S1's inferential disability.

\section{Divergent shift analysis}

S1's responses were characterised by few conceptual shifts (Total $=3$ conceptual shifts $)$ and a low proportion $(30 \%)$ of matching inferences. S2's responses were divergent, with a high level of conceptual shifting (Total $=10$ conceptual shifts) and a high proportion of matching inferences $(90 \%)$.

\section{eg. Poor conceptual shifting Item 6 [Subject 1)}

E: Eric was grateful to his Uncle Fred because ...

S: (1) Because his uncle could let him use the bike ...
(2) Because his uncle let him ride it.

Number of matching inferences in above example $=0 / 2$. Neither of the above inferences matched the correct responses listed for item 6 (b, d).

\section{eg. Good conceptual shifting Item 1 (Subject 2)}

E: Jack didn't leave a tip because -

S: (1) Because the restaurant wasn't good. The food was bad and the service was bad.

(2) He never had any small change on him.

Number of matching inferences in above example $=2 / 2$.

These 2 inferences above matched the correct responses listed for item $1(b, d)$.

\section{Congruency analysis}

S1 tended to ignore congruency between response alternatives, reflecting difficulty with simultaneous analysis and synthesis, suggesting a cognitive lag. This difficulty has been noted in the language-learning disabled population (Crais and Chapman, 1987; Ellis Weismer, 1985), as well as in younger normal children (Paris and Lindauer, 1976).

\section{TEST. OF INFERENTIAL COMPREHENSION 1}

Both subjects performed adequately on this test, which relied primarily on schematic knowledge, rather than linguistic context. However, S2's responses were more divergent, and contained more conceptual shifting.

\section{TEST. OF INFERENTIAL COMPREHENSION 2}

This test was analysed in terms of the effect of factor variation on inferential ability (see table 3). It was found that the factors or forced reliance on schematic knowledge, reversible embedding and passivization, and unclear intersentential relationships, had an adverse effect on only S1's performance. Both subjects' performance was adversely affected by complex vocabulary level and the presence of an interceding inference. However, S1's problems resulted in more extensive utilization of the deficient strategies described in the T.O.L.C. analysis.

Table 3: Results of inferential comprehension test 2

\begin{tabular}{|c|c|c|}
\hline FACTORS & S1 & S2 \\
\hline Vocabulary & $1-1$ & $(-1$ \\
Schematic knowledge & $(-1$ & N.E. \\
Embedding (NR) & N.E. & N.E. \\
(R) & (-) & N.E. \\
Passivization (NR) & N.E. & N.E. \\
(R) & $(-)$ & N.E. \\
Microstructure & $(-1$ & N.E. \\
Interceding inference & (-) & (-) \\
\hline
\end{tabular}

$$
\begin{aligned}
\text { KEY: NR } & =\text { Non-reversible } \\
\text { R } & =\text { Reversible } \\
\text { N.E. } & =\text { No effect on performance } \\
1-1 & =\text { Adverse effect on performance }
\end{aligned}
$$


Non-reversible passivization and embedding had no effect on the subjects' comprehension, since the paragraph content was highly predictable due to the presence of semantic constraints.

S1's breakdown in inferential reasoning, precipitated by some of the factors listed above, paralleled his inferior results on the correlation tests. This confirmed previous findings of such deficits in the learning-disabled population (Wiig \& Semel, 1976; 1984).

S2's performance was not affected by the influence of the factors studied, with the exception of vocabulary level and presence of an interceding inference. S2's responses were generally hypothetico-deductive and formal-operational, in contrast to S1's concrete syncretic reasoning.

Although both subjects' comprehension was affected by the level of vocabulary complexity, the subjects reacted differently to this factor. S1 resorted to a syncretic response, before attempting a strategy of overreliance on real world knowledge. $\$ 2$ also ignored difficult lexical items but did not use ptimitive syncretic strategies. Instead, he used a more appropriate strategy of imposing linguistic coherence by integrating what he had understood with his real world knowledge.

With regard to the interceding inference factor, $\$ 1$ made an incorrect interceding and final inference. S2's deduction of the interceding inference was influenced by residual preoperational difficulty with distinguishing real world from imaginary events (Phillips, 1971). The relationship between imagination and inferential ability has not been addressed in the literature, but may be of interst for further investigation.

\section{CONCLUSIONS}

The findings of this study suggested that the nat ure of learning-disability could be conceptualised in terms of a verbalcognitive interactional model. The study of inferential ability permits generalizations about verbal and cognitive skills, since both verbal and cognitive knowledge are required to engage in inferential reasoning.

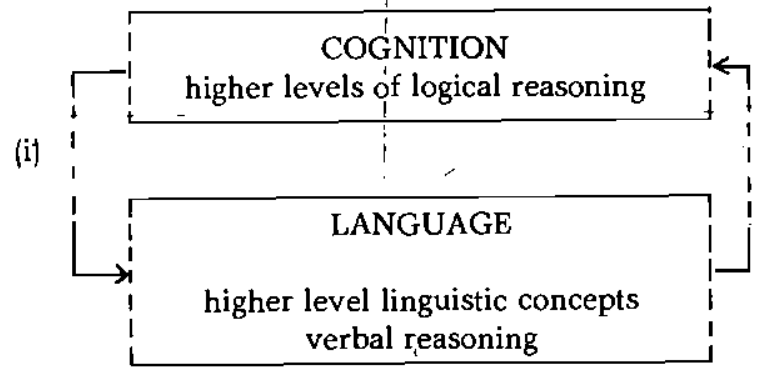

Figure 3: Interactional model of verbal-cognitive dynamics

The main conclusion of this study was that the performance discrepancies documented, pointed to deficiencies in verbal-cognitive ability or 'verbal thought' (Vygotsky, 1962) (see figure 3). The language-learning disabled child presented with:-

- Cognitive deficits that interfered with the growth of formal verbal reasoning and the acquisition of higher level linguistic concepts. This would be in agreement with
Bryen (1981) who asserted that "... this linguistic delay is not caused by inability to acquire certain linguistic symbols, but rather by reduction or delays in the acquisition of logical structures that determine their meaning".

- Linguistic deficits that possibly interfered with the development of higher levels of logical thinking and conceptual thought, as asserted by Bruner (cited by Lerner, 1976), and Piaget (1967).

However, the exact interactional dynamics between cognition and language in learning disabilities is still a topic of controversy as reflected in the following conclusion:-

"The degree to which language delay contributes to or is a function of ... cognitive delay must still be determined" (Gerber, 1981). However, it must be noted that a limitation of the study was the use of only 2 subjects which restricted a generalisability of the study. The study should be replicated on a larger sample in order to verify results. In addition, future research should address the issue of subjective evaluation by making use of more than one rater, and ensuring inter-rater reliability."

This study highlighted the fact that comprehension is a multi-faceted process and that various aspects of this ability should be considered in therapy. The results of this study, when considered within the theoretical framework proposed earlier, suggest that therapeutic intervention could be systematically organized to focus on various components considered by the model of inferential ability described. This study outlined certain areas of particular importance for therapy with a patient with inferential deficits and strategic breakdown. Therapy should consider such areas as schematic induction and accessing, a higher level linguistic deficits. Therapy could focus on the comprehension of causal relations and other connective relationships. Therapy should also stress comprehension of anaphoric devices and memory strategies [Gerber, 1981; Klein-Konigsberg, 1984). Therapy should emphasise lawful divergence and formulation of plausible hypotheses. Finally, the therapist should stress the importance of the listener's perspective and encourage explicit reasoning and an analytical orientation.

This study generated some implications for further research. Developmental studies of inferential abilities in both normal and learning-disabled populations, are needed. Other factors of the inferential comprehension model outlined earlier, may be investigated, such as the influence of level of abstraction, text organization or other categories of inference, on inferential strategies. The relationship between inferential ability and imagination has not been addressed in the literature, and constitutes an interesting area for investigation. The relationship between inferential comprehension and academic performance also needs to be considered in more depth, and the relationship between cognitive and linguistic deficits in learning disability warrants more attention. Finally the construction of assessment tools for evaluating inferential comprehension skills, is required.

The study of inferential ability holds interesting theoretical and practical implications for both speech therapists, educationalists and researchers. The continued investigation of this area is important, in view of its potential to clarify many controversial issues related to language pathology. 


\section{REFERENCES}

Berry, M. Language Disorders in Children. Appleton-Century Crofits, New York, 1969.

Bransford, J.D. and Pranks, J.J.: The abstraction of linguistic ideas. Cognitive Pshychology, 2, 331-350, 1971.

Bryen, D.N. Language and language problems. In: A. Gerber and D.N. Bryens (Eds). Language and Learning Disabilities. University Park Prcss, Baltimore, 1981.

Carroll, D.W. Psychology of Language. Brooks/Cole Publishing Company, Montery, California, 1986.

Crias, E.R. and Chapman, R.S. Story recall and inferencing skills in language learning-disabled and non-disabled children, Journal of Speech and Hearing Disorders, 52, 50-55, 1987.

Danner, F.W. and Mathews, S.R. When do young children make inferences from pose? Child Development, 51,906-908, 1980.

Dunn, L.M. Peabody Picture Vocabulary Test. American guidance service, Minneapolis, 1965.

Ellis Weismer, S. Constructive Comprehension abilities exhibited by language-disordered children. Journal of Speech and Hearing Research, 28, 175-184, 1985.

Falstein, M. and Miller, L.V. Predicting Outcomes: Reading from Comprehension. Educational Insights, Compton, California, 1980.

Gerber, A. Processing and use of language in education. In: A. Gerber and D.N. Bryen |Eds\}. Language and Learning Disabilities. University Park Press, Baltimore, 1981 (a).

Gerber, A. Remediation of langauge processing problems of the school-age child. In: A. Gerber and D.N. Bryen (Eds). Language and Learning Disabilities. Univerity Park Press. Baltimore, 1981 (b)

Hammill, D.D., Brown, V.L., Larson, S.C. and Wiederholt, J.L. Test of Adolescent Language. Pro-Ed, Austin. Texas, 1980

Johnson, M.K., Bransford, J.D. and Solomon, S.K. Memory for tacit implications of sentences. Journal of Experimental Psychology 98(1), 203-205, 1973.

Kail, R.V., Chi, M.T., Ingram, A.L. and Danner, F.W. Constructive aspects of children's reading comprehension. Child Development, 48, 684-688, 1977 .

Klein-Konigsberg, E. Semantic intcgration and language learning disabilitics: From Research to assessment and intervention. In: G.P. Wallach and K.G. Butler (Eds). Language Learning Disabilities in School-age Children. Williams \& Wilkins, Baltimore, 1984.

Lerner, J.W. Children with Learning Disabilities: Theories, Diagnosis and Teaching Strategies. Houghton Mifflin Company, Boston, 1976.

Moates, D.R. and Schumacher, G.M. An Introduction to Cognitive Psychology, Wadsworth Publishing Company, Inc., Belmont, California 1980
Nelson, N.W. Beyond information processing: The language of teachers and textbooks. In: C.P. Wallach \& K.G. Butler (Eds) Language Learning Disabilities in School-age Children. Williams and Wilkins, Baltimore, 1986.

Parades, K. Drawing Conclusions. Frank Schaffer Publications, Inc. California, 1980.

Paris, S.G. and Carter, A.Y. Semantic and constructive aspects of sentence memory in children. Developmental Psychology, 9(1), 109-113, 1973

Paris, S.G. and Lindauer, B.K. The role of inference in children's comprehension and memory for sentences. Cognitive Psychology, 8, 217-227, 1976.

Penn, C. A linguistic approach to the detection of minimal language dysfunction in aphasia. Unpublished undergraduate research report, Department of Speech Pathology and Audiology, University of the Witwatersrand, 1972.

Phillips, J.L. Piaget's Theory: A Primer. W.H. Freeman and Company, San Francisco, 1971.

Piaget, J. The language and thought of the child \{1923\}. In: H.E. Grohen and J.J. Vonéche (Eds). The Essential Piaget. Routledge \& Kegan Paul, London, 1977.

Piaget, J. Judgment and rcasoning in the child (1927). In: H.E. Groher and J.J. Vonéche (Eds). The Essential Piaget. Routledge \& Kegan Paul, London, 1977.

Piaget, J. Six Psychological Studies. University of London, 1967.

Reed, S.K. Cognition: Theory and Applications. Brooks/Cole Publishing Company, Montery, California, 1982.

Semel, E.M. and Wiig, E.H. Clinical Evaluation of Language Functions. Charles E. Merrill Publishing Company, A. Bell \& Howell Company, Columbia, Ohio, 1980.

Thorndyke, P.W. The role of inferences in discourse comprehension. Journal of Verbal Learning and Verbal Behaviour, 13 , $437-506,1976$

Tombak, Y. Inferential comprehension strategies in a languagelearning disabled child. Unpublished undergraduate research report, Department of Speech Pathology \& Audiology, University of the Witwatersrand, 1987.

Vygotsky, L.S. Thought and Language, 5 M.I.T. Press, Massachusetts, and John Wiley \& Sons, Inc., New York, 1962.

Westby, C.E. Development of narrative language abilities. In C.P. Wallach and K.G. Butler \{Eds\}. Language-learning Disabilities in School-age Children. Williams \& Wilkins, Baltimore, 1984.

Wiig, E.H. and Secord, W. Test of Language Competence. Charles E. Merrill Publishing Company, A. Bell \& Howell Company, Columbus, Ohio, 1985.

Wiig, E.H. and Semel, E.M. Language Disabilities in Children and Adolescents. Charles E. Merrill Publishing Company, Columbus, Ohio, 1976.

Wiig, E.H. and Semel, E.M. Language Assessment and Intervention for the Learning-disabled. Charles E. Merrill Publishing Company, A, Bell \& Howell Company, Columbus, Ohio, 1984. 
Appendix 1: Test of language competence (Wigg \& Secord, 1985) Subtest 2: Making inferences
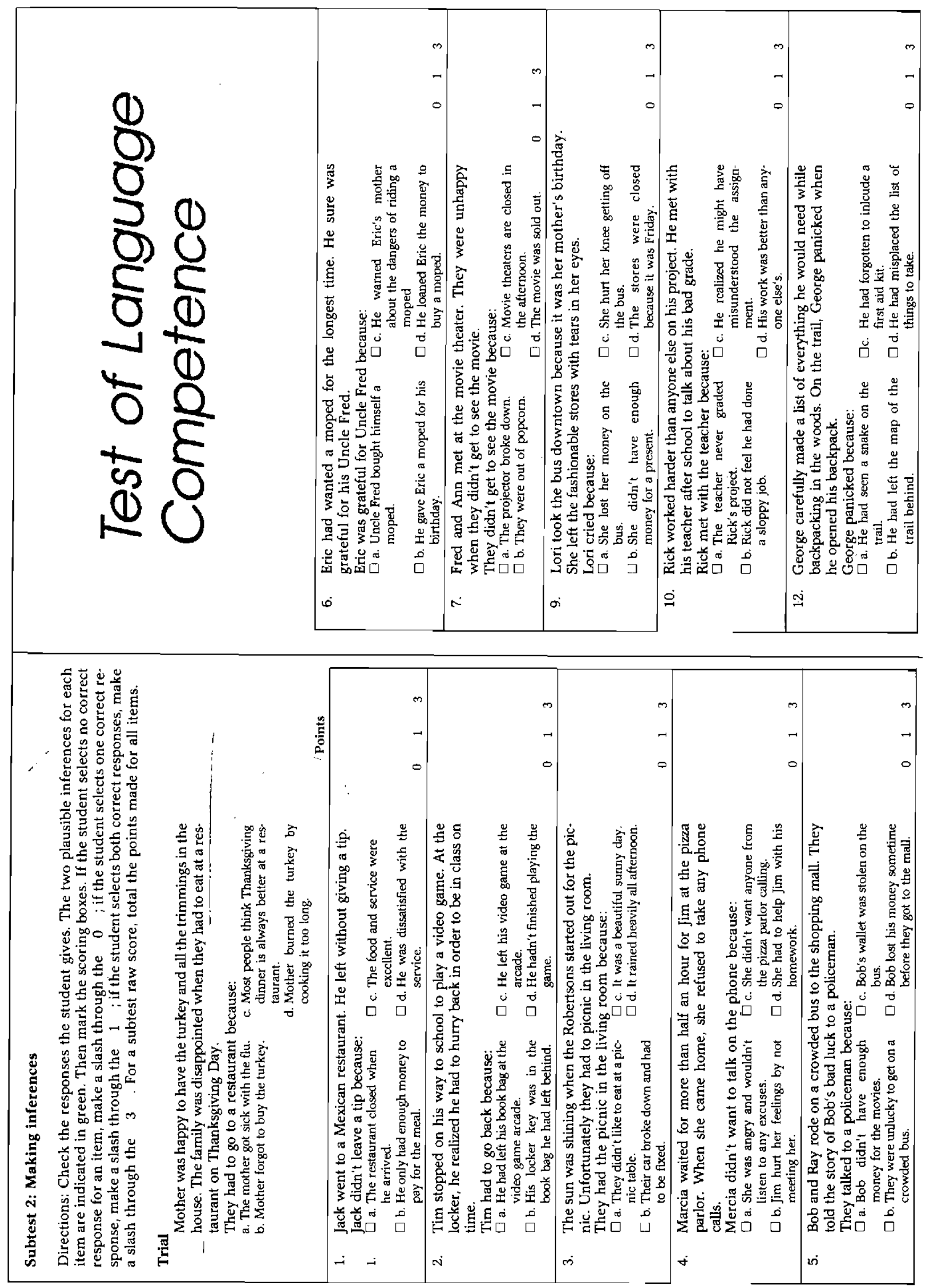


\section{Appendix 2: Test of inferential comprehension 1}

\section{A. INFERENCE OF EVENT}

1. Antecedent inference

a. Alan came home from school.

He gave his mother the teacher's note.

Why had the teacher sent the note?

b. Paul went to the shops to buy yoghurt.

He came home without the yoghurt.

Why did Paul come home without the yoghurt?

\section{Interceding inference}

a. Mrs Ray received a dress by post.

She had to take it back to the shop.

Why did Mrs Ray have to take the dress back?

(Adapted from Paredes, K.: Drawing Conclusions, Card 23(3). Frank Schaffer Publications, Inc., California, 1980 ).

b. John had to pay a lot of money for the repairs.

On his way home, he did not give the beggar any money.

Why didn't John give the beggar any money?

3. Future inference

a. Mrs Dean wanted a certain book about gardening.

The bookshop did not have it.

What do you think Mrs Dean will do?

(Adapted from Paredes, K: Drawing Conclusions, Card 27(2). Frank Schaffer Publications, Inc., California, $1980)$.

b. Greg pressed his face against the window.

He wanted to see how the chefs made pizza.

Suddenly the window steamed up.

What do you think Greg will do?

(Adapted from Paredes, K: Drawing Conclusions, Card 27|2|. Frank Schaffer Publications, Inc., California, $1980 \mid$.

\section{B. INFERENCE OF SUBJECTIVE STATE}

1. Reaction-based inference

a. Leah had a test.

Afterwards, she tore the test paper into little bits.

How did Leah feel about the test?

b. Dave teased Eric.

Then, he pinched him

How did Dave feel about Eric?

\section{Stimulus-reaction based inference}

a. Steve told his dad about the movie.

His dad said he would go see it the next day.

- What did his dad think of Steve's description of the movie?

b. Dad asked Mat to bring his toolbox.

"I left it over at Larry's. He needed it."

Dad muttered something under his breath.

How did Dad feel about the toolbox being left at Larry's house?

(Adapted from Paredes, K.: Drawing Conclusions, Card
27\{2\}. Frank Schaffer Publications, Inc., California , 19801 .

3. Stimulus-based inference

a. At last, Merilyn had almost finished the painting

She had worked many months on it.

All her friends praised her.

How do you think Marilyn will feel when she finishes the painting?

(Adapted from Paredes, K.: Drawing Conclusions, Card 15(2). Frank Schaffer Publications, Inc., California, 1980).

b. Shelly's aunt sent her a present.

It contained an ugly pair of green socks.

How do you think Shelly will feel about the present?

\section{Appendix 3: Test of Inferential Comprehension 2}

\section{A. INFERENCE OF EVENT}

1. Antecedent inference

$$
\pm \text { Vocabulary }
$$

a. Paul walked slowly down the hall, wondering what to do. As he stood before the door of the principal's office, he felt ashamed. He considered going home rather than facing Miss Conlin. She would be so disappointed in him. Paul had always been an excellent student and he was never known to lie or cheat. It was only because his mother had been ill and he had to help take care of his brothers and sisters that he'd had to do it. Paul took a deep breath and knocked lightly on the principal's door. Miss Colin called out "Come in!"

Give some reasons why Paul had been sent to the principal's office. (Adapted from Falstein \& Miller 1980. Predicting Outcomes, Cart 35: 'The best policy'.

b. As Mr Dean loped down the passage towards the manager's office, he felt that he was a despicable person. Mr Dean mounted the flight of stairs, considering all plausible alternatives as to his course of ensuing action. He realised that the possibility of squirming his way out of this tricky situation was highly remote. The manager would be highly disappointed by his treacherous behaviour. Mr Dean had always been considered a reputable employee and had never been known to engage in fraud, sabotage or forgery. It was only because of the dire financial straits of his family that he had felt compelled to participate. Mr Dean tapped briskly on the manager's door, and he was told to enter.

Give some reasons why Mr Dean had been called to the manager's office.

2. Interceding inference

\pm Schematic information

a. Granny Jean was really proud of her grandchildren. She visited them almost everyday. She really enjoyed the visits to them. Since the sun was shining, she decided to take a walk, rather than drive. Spring was in 
the air, and the blossoms looked beautiful. By the time Granny Jean reached the house, the sky had clouded over. Granny enjoyed the tea and thought the scones were particularly delicious. She soon felt very tired. Granny realised that she would need to hurry since it was late and she still wanted to visit a friend of hers. She got up to leave. However, she realised that she would have to go back by taxi.

Give some reasons why she had to go back by taxi.

b. Uncle Tim was the laziest man anyone had ever heard of. He was so lazy that he never walked anywhere. One day, Uncle Tim decided to visit a friend of his. As usual, he took his car. He always drove, since he was too lazy to walk. The drive was very enjoyable, and the gardens looked picturesque. Uncle Tim finally reached the house. He watched TV at his friend's house, and Uncle Tim thought that the Western was particularly exciting. Finally, Uncle Tim decided to leave, because he wanted to get to bed early. However, he soon realized that he would have to walk home.

Give some reasons why he had to walk home.

3. Future inference

\pm Reversible embedding

a. Marlene got a beautiful new watch for her birthday. She looked after it carefully and never let anyone touch it. Lisa was her best friend. She loved beautiful things but no-one ever trusted her with anything. This was because Lisa was a very careless girl. She didn't know how to look after things properly. Although Lisa begged Marlene to lend her the watch, she always refused. One day, Marlene and Lisa went to the movies. Marlene fell asleep. Lisa decided to wear the beautiful watch for a few minutes even though it was to dark to see the time.

What do you think will happen next?

b. The boy the girl knew, liked to collect stamps. The girl the boy had seen, had a stamp collection that grandfather had given to the family. The girl, the boy who liked stamps had tried to persuade, never brought the stamps grandfather had given to school. One day, the friends convinced the girl the boy had seen, to bring the valuable stamp collection that grandfather had forbidden to take to school. The boy the girl knew, was very excited that they would see the stamps, that many collectors really wanted. The girl, the boy knew would bring the stamps, did not know how much the stamps were wanted by collectors.

What do you think will happen next?

\section{B. INFERENCE IN SUBJECTIVE STATE}

1. Reaction-based inference

\pm Reversible passivization

a. This is what Michele was planning to do. As soon as Shirley would look away, she would take her pencil- box. She would then keep her favourite ice cream rubber for her own collection. Then she was planning to scatter all the other contents over the classroom. That would make Shirley appear careless. Then the teachers wouldn't believe her claim that someone may have stolen the beautiful rubber. In fact, they would all shout at Shirley for being so careless and losing it.

How did Michele feel about Shirley? Why do you think so?

b. A revenge had been planned by John. Eric would be invited by John to a party. He would be given cold drinks by John. Since the cold drinks would contain a sleeping powder, it would knock him out. Eric would be carried by John to a friend's house. He would then be locked in a dark cupboard. Eric would then be threatened by John. He would threaten to keep him there if he would not apologise. He would then be made to promise never to tell anybody of what had happened.

How did John feel about Eric?

Why do you think so?

2. Stimulus-reaction based inference \pm Microstructural aspect

a. Hannah Henessee was a young woman whose husband was away in the army. She had to take care of the farm and the children. When Hannah returned home one day, she discovered that the Indians had kidnapped her children. They had carried the children away across the wide dangerous river. Hannah swam across the deep water and walked into the Indian camp. She demanded that the Indians return her children. The Indians were so surprised that they allowed her to take her children home.

How did Hannah feel about the Indians? How did the children feel about Hannah?

(Adapted from Falstein \& Miller, 1980, Predicting Outcomes, Card 37: 'A revolutionary Heroine' $\%$.

b. Alex Black was a young boy whose parents were away on holiday. Relatives took care of the child in the meanwhile. Everybody spoke of the highwaymen that had kidnapped many people. Many caves in a nearby mountain provided a good place to keep hostages. A short trip by train led across desert towards the mountain. Terrified faces met the entry of a young boy with his silver gun. Soon, the group of hostages sped back to town by train.

How did Alex feel about the highwaymen? How did the hostages feel about Alex?

3. Stimulus-based inference \pm Intermediate inference

a. When the Don family visited the old ranch, Roy was the first! to explore the cellar. The most exciting thing he found that day was an old sheaf of papers contain- 
ing diary notes and maps. One of the maps was crumpled, faded and very interesting. This map contained directions for finding a treasure. It took him some time, but Roy finally figured out the directions. He walked three steps to the left of the old farmer's barn, then he turned right and measured out three meters in that direction. Finally he reached the spot from which he could see two apple trees. The directions said that if he would walk to the ditch behind the tree on the right and dig down two meters he would reach the treasure chest. Roy had been digging for about ten minutes when his spade struck the lid of the chest.

How will Roy feel when he sees the contents of the chest?

How will his family feel when they hear of the find? find?

b. When the Bascomb family moved into the old house,
John was the first one to explore the attic. The most interesting thing he came upon that day was an old trunk filled with books and papers. One book's pages were cracked, yellow and particularly hard to read. This book contained a recipe for making gold. It took him a while, but John finally gathered all the ingrediants. Gold, after all, was something everyone could use more of. One day, while his family was out, John boiled twelve eggs. He then mixed them with manure from a white cat and added the juice of four grapefruits. He boiled that mixture for three hours. The recipe said that if any metal, such as tin or iron, was dipped into the mixture it would turn to gold. John had a tin can and three iron nails.

How will John feel after he dips the metals in the mixture? How will his family feel when they hear what he had done?

(Adapted from Falstein \& Miller, 1980, Predicting Outcomes, Card 31: 'The alchemist'). 